\title{
Stirring up Engineers' Systems Intelligence: A Case Study of Life-Philosophical Pedagogy
}

\author{
https://doi.org/10.3991/ijep.v7i3.7252 \\ Pia Lappalainen \\ Aalto University, Language Centre \\ pia.lappalainen@aalto.fi
}

\begin{abstract}
In their role as problem solvers, engineers are expected to take responsibility for the grand societal challenges that require technical expertise and innovation. This urges them to broaden their horizon from the traditional, deeply technological world view to one that examines the surrounding globe with empathy and social responsibility. Such a call for systems intelligence necessitates a novel approach to engineering education to allow students to practice systemic capabilities.

As methodology, life-philosophical pedagogy was experimented with in an English language course that was integrated with the Philosophy and Systems Thinking lecture series. Such pedagogy deviates from conventional methodology in that instead of focusing on correcting deficiencies and filling competence gaps, it takes a midwife approach and recognizes the potential in individuals and delivers the abundance in them. The principles of positive psychology and frameworks of socio-emotive intelligence guide the reflective workout in the course, catalyzing, stimulating and rooting new thinking. Ultimately the course promotes self-growth, intentional change and overall life management, while allowing students to hone various interpersonal skills relevant for industrial tasks.
\end{abstract}

Keywords-Systems intelligence; life-philosophical pedagogy; socio-emotive skilling

\section{Systems intelligence as an emerging competence requirement}

Engineers are often the key instigators of forward movement in our society [1]. In their role as problem solvers, they struggle with the wicked problems that require technical expertise and innovation. Logically, domain knowledge persists as the selfevident foundation of their professional expertise, embracing theoretical, practical, technical, strategic and conceptual capacity [2] that allows them to design physical solutions to identified needs [3]. The trends in society, the emerging changes in industrial operating environments, and the subsequently growing demands for wider competence bases, however, necessitate an updating of competences to facilitate contextual performance in organizations and in society at large [4]. 
As efforts to respond to these universal developments in the engineering world, the past decades have seen the emergence of new types of engineering pedagogics that pursue holistic professional development: problem-based learning, project-based learning, integrated approaches, CDIO, student-centred learning, students-asconsumers and integrated education, among others. As teamwork has become the norm in working life to the extent that presently $60 \%$ of the workforce belong to at least one team [5], higher engineering education is increasingly adopting teamwork and replicating industrial project-type organization to allow students to hone their team membership skills [6].

As subsequent novel yardsticks for judging and developing engineers' qualifications, recent studies have proposed that pedagogical attention be shifted to personal attributes, such as personality [7,8], socio-emotive competence $[9,10,11]$ and systems intelligence [12]. Systemic capability refers to the ability to act intelligently as part of and in relation to the whole, even in the absence of knowledge of the whole [13]. The whole in the present context addresses economic and social contexts of any scale, from small projects to society-wide set-ups.

Even though attention in systemic thinking is directed outwards to embrace the whole, the required capacity build-up requires awareness of what is within the self. To this regard, recent literature has investigated the role of personality; among personality dispositions, especially conscientiousness and agreeableness are traits that are known to influence not only individual performance but also team functioning [14]. In a similar vein, various models of socio-emotive ability $[15,16,17,18]$ show that the foundation of social, interpersonal ability lies on intrapersonal capacity - the social and the solitary are intertwined.

The global dimension of engineering education seeks a higher-level systemic understanding and world view, reacting to societal demands posed on the engineer's role. The personal dimension provides the foundation for systemic thinking but pursues, in contrast, a profound and sustained transformation of the self, founded on reflective practice and cultivation of self-growth. Both digress from echoing or imitating lecturer-provided information towards vitalizing life-philosophical thinking and catalyzing the birth of the reflective self [19]. The novel configuration of abilities seems 'unparsed' in that it subsequently addresses two opposing directions of competence development - global and personal, but paradoxically, the polarity constitutes a complementary rather than a competing framework of requirements.

Despite the oddity of these learning objectives within traditional engineering curricula, there is nothing paranormal or esoteric about these themes. Rather, despite of moving beyond any cognitive position or paradigm, they form a learning platform that only seemingly takes a revolutionary form, while being deeply rooted in Socratic legacy. In brief, the philosophy simulates a midwife approach: instead of focusing on correcting student deficiencies and filling competence gaps, it takes an interest in the abudance or the potential that students bear [20].

To stir up and further expand students' personal capacities, studies [21] have advocated eight types of classroom activities: mining past experiences, self-assessment, storytelling and case writing, drama, negotiation, cross-cultural exchanges, classroom as organization, and learning through emotion. Life-philosophical pedagogy is, in 
fact, a platform integrating several of these but in more subtle or tacit and less articulated means: learning is supported by suggestive rather than instructive content through non-directive guidance. As a classroom practice, it is characterized by humanity, indirectness, obliqueness, non-consciousness, non-conceptuality, nonverbalness, implicitness, mindfulness, the emotional realm and associations. It allows time and space for revisiting old experiences and memories, thus enabling reinterpretations and elucidation of familiar themes [22].

With its attentive focus on learner potential and heedful appreciation of and faith in students' unleashed abilities, life-philosophical pedagogy is strongly aligned with the principles of positive psychology. Building on findings from psychology is well substantiated as recent research evidences an association between employee affects and organizational outcomes [23]. This indicates that emotions constitute pivotal job resources incrementing employees' psychological, social, physiological and intellectual capacity and well-being [24].

Further, numerous studies support the predictive value of relational abilities in a leader in terms of career progress [25], subordinate achievement, and ultimately organizational outcomes [26]. Such impacts on organizational performance are impressive and relevant in the engineering context, as most engineers end up taking on managerial tasks at some point in their careers [27].

Finally, researchers call for new pedagogy to attend to learner craving for encouragement, engagement, care and being treated as a whole, and to societal demands for going beyond the subject matter [28]. This paper is a case study, depicting an endeavour responding to these needs. The endeavour is a pilot course integrating English language learning objectives and communication themes into the platform of a Philosophy and Systems Intelligence course. This report outlines the course design and reflects on the lessons learned.

\section{$2 \quad$ Learnability of systems intelligence}

Systems intelligence is polemic in educational terms, the central question determining its inclusion in engineering programs being whether socio-emotive competences can be taught. Two competing paradigms account for the origin of social and emotional intelligences: the first treats interaction behavior as biological and dependent on innate traits. Indeed, the key acumen has for long been the understanding that human beings are endowed with abilities for emotional and non-verbal exchange already at infancy [29].

The second views human conduct as associated with certain competences, e.g. social competence, or teachable and learnable skills [30]. Skill refers to an acquired ability that improves as a consequence of deliberate practice [31], but accumulating evidence shows that also maturational trends and significant life course transitions induce changes in an individual's emotional intelligence even at later stages of life [32]. Such development is triggered by neurobiological changes, growing conceptual skills, and social influences and outsider interventions. Social interaction with the surrounding world is instrumental in shaping emotion management ability and strate- 
gies that help individuals interpret, appraise and control their feelings and behavior [33].

Engineers have for long suffered from commonly held prejudices that view them as possessing inferior emotional intelligence skills compared to many other professions. Some studies [34] have, in fact, detected slightly lower scores in emotional intelligence in engineering samples, but such results are growingly accounted for by the infrequent emotional skilling available in higher engineering education.

Myriad studies [35, 36] confirm the learnability of personal attributes - the emotional quotient increases as a result of persistent training. But an important consideration when designing interventions is the finding that many of the human characteristics are formed outside of awareness, which is why we need to learn self-awareness and self-affirmation strategies. Additionally, individuals need feedback on how their behavior affects others. Therefore, the surrounding community is decisive for personal development and learning; people need others against whom to mirror their emotional capacity, but they also need a safe environment where to analyze and reflect on their progress towards the ideal self [37]. A critical requirement is the individual's motivation for growth and renewal but encouragingly, willingness to commit to selfdevelopment in the area of soft skills will result in concrete benefits impacting one's overall life quality, but also that of the others [38].

The following section describes a curriculum development endeavour that aimed to allow students to hone their socio-emotive competence and systemic intelligence in alignment with the university quest for leveraged graduate employability, smoother induction to working life, and more intensive personal growth.

\section{The experiment}

Life-philosophical pedagogy deviates from traditional methodology in that instead of focusing on remedying student deficiencies and filling competence gaps, it takes a midwife approach and helps recognize the potential in the individuals and deliver the abundance, the potential, in them [39]. In the pilot endeavor in question, principles of positive psychology [40] and frameworks of social and emotional intelligence [41] guided the reflective workout in the course, helping catalyze, stimulate and root new practices into engineering students' everyday lives and thinking. Ultimately the course promoted self-growth, self-affirmation, intentional change and overall life management, while allowing students to practice various interpersonal skills relevant in industries. Self-affirming and self-awareness tasks encouraged students to reflect on their values and qualities, strengths and weaknesses, which is known to yield positive long-term impacts on their academic performance, professional growth and social behavior, and promote overall systemic thinking [42].

The educational experiment reported here is founded on novel educational philosophy, complemented with recent knowledge of socio-emotional intelligence as comprising two levels of capacity: intrapersonal or emotional, and interpersonal or social. The experiment addressed these levels through self-reflective and reaction exercises that enabled developing such critical components of affective capacity as self- 
knowledge, self-motivation, self-image, self-regulation, social awareness and empathy [43], all constituting fundamental sub-skills of systems intelligence. These classroom activities leverage students' self-leadership ability and relationship management for the benefit of their future workplaces and overall life quality. The ultimate aim was to equip engineering graduates with aptitude in holistic, systems-level thinking, in order to allow them to leave their footprint in a kinder, more considerate world.

\begin{tabular}{|l|l|}
\hline \multicolumn{1}{|l|}{ Theoretical foundation } & \multicolumn{1}{c|}{ Learning objectives } \\
\hline $\begin{array}{l}\text { Competing Values framework } \\
\text { (Rogers \& Hildebrandt, 2003) }\end{array}$ & $\begin{array}{l}\text { Audience focus } \\
\text { Ethos-logos-pathos-telos }\end{array}$ \\
$\begin{array}{l}\text { Social Competence model } \\
\text { (Bar-On, 2006) }\end{array}$ & $\begin{array}{l}\text { Self-leadership } \\
\text { Social intelligence }\end{array}$ \\
$\begin{array}{l}\text { Intentional Change theory } \\
\text { (Boyatzis \& Akrivou, 2006) }\end{array}$ & $\begin{array}{l}\text { Self-motivation } \\
\text { Self-management } \\
\text { Broaden and Build } \\
\text { (Fredrickson, 2004) }\end{array}$ \\
$\begin{array}{l}\text { Life-Philosophical pedagogy } \\
\text { (Saarinen, 2015) }\end{array}$ & $\begin{array}{l}\text { Emotive reservoirs } \\
\text { Personal growth }\end{array}$ \\
\hline
\end{tabular}

Fig. 1. The theoretical foundation and the related learning objectives.

\subsection{Course design}

The course in question was an integrated English course, that is, it integrated the key English principles adopted as the university foreign language framework into the key contents from the parent course. The parent course Philosophy and Systems Intelligence offered themes from positive psychology, systems intelligence and philosophy, while the English component addressed the key English teaching principles of readability, organization and style, in alignment with regular language courses at the university.

This 36-hour course was organized into 9 sessions, 4 hours each, as depicted in Table 1. 
Table 1. The course design and organization.

\begin{tabular}{|c|c|c|c|c|c|}
\hline SESSION & \begin{tabular}{|l} 
CONTENT \\
-Systems Intelligence
\end{tabular} & $\begin{array}{l}\text { LANGUAGE FOCUS } \\
\text {-WRITIEN }\end{array}$ & $\begin{array}{l}\text { LANGUAGE FOCUS } \\
\text { - ORAL }\end{array}$ & READING & HOME ASSIGNMENIS \\
\hline 1 & $\begin{array}{l}\text { Industrial competence req's } \\
\text { Holistic capability }\end{array}$ & $\begin{array}{l}\text { Academic style } \\
\text { Formality } \\
\text { Dynamic verbs }\end{array}$ & $\begin{array}{l}\text { Student introductions: } \\
\text { Relationship with SI }\end{array}$ & Nerburn & 1.Personal values statement \\
\hline 2 & Productivity, health and SI & $\begin{array}{l}\text { Aims and relevance } \\
\text { Categories of topic } \\
\text { relevance } \\
3 \text { categories of aims }\end{array}$ & $\begin{array}{l}\text { Discussion in small groups: } \\
\text { Integration of SI into higher } \\
\text { education }\end{array}$ & Saarinen & 2. Project plan draft \\
\hline 3 & Broaden and build & $\begin{array}{l}\text { Summarizing } \\
\text { CaRS } \\
\text { Cancision vs } \\
\text { redundancy }\end{array}$ & $\begin{array}{l}\text { Students as opponents: } \\
\text { Peer review of project plan }\end{array}$ & Fredrickson & 3.Abstract draft \\
\hline 4 & Social competence model & $\begin{array}{l}\text { Making claims } \\
\text { Topicalization } \\
\text { Listing evidence }\end{array}$ & $\begin{array}{l}\text { Encouraging and inspiring: } \\
\text { Peer review of abstract }\end{array}$ & Bar-On & 4.Final abstract \\
\hline 5 & Personality and plasticity & $\begin{array}{l}\text { Data commentary } \\
\text { Reporting verbs } \\
\text { Synthesizing }\end{array}$ & Presentation of project status & Boyatzis \& Akrivou & 5. Written project plan \\
\hline 6 & Intentional change & $\begin{array}{l}\text { Coherence } \\
\text { Connecting ideas } \\
\text { Relative clauses }\end{array}$ & $\begin{array}{l}\text { Students as trainers: } \\
\text { Self-leadership }\end{array}$ & Yu \& Hyonsong & \\
\hline 7 & \multicolumn{4}{|c|}{ INDIVIDUAL TEACHER FEEDBACK ON ABSTRACT } & \\
\hline 8 & \multicolumn{4}{|c|}{ PROJECT IMPLEMENTATION } & 6.Prepare for project presentation \\
\hline 9 & \multicolumn{4}{|c|}{ PRESENTATION OF PROJECT OUTCOMES } & 7. Reflective Journal \\
\hline
\end{tabular}

To ensure completion of both oral and written language requirements in alignment with the university policy for foreign language teaching, the class activities addressed both components. The grading was based on written performance in four written assignments and oral performance in one presentation. All except for the project plan and presentation were individual assignments:

1. Personal Values Statement: individually graded, 20\%. In this 300-word assignment, students described two or three of their personal or professional values by providing supporting evidence of their daily implementations of these virtues in practice. Reflection of one's values enhances self-knowledge and guides decisionmaking as the individual becomes more aware of ideals he/she is unwilling to compromise.

2. Abstract for an academic article on positive psychology: individually graded, $\mathbf{2 0} \%$. Summarizing is an important working life skill enhancing team effectiveness. This activity allowed students to practice condensing larger entities into concise statements while applying formal language, coherence strategies, and terminology related to positive psychology.

3. Systems intelligence project plan: group-graded, pass/fail $\mathbf{2 0 \%}$. The students worked in small groups, designing and implementing a 'Do Good' project with one of the local stakeholder groups. The project allowed students to implement sys- 
tems-intelligent ideals in a real-life endeavor but also to acquire project management skills. The idea was to understand requirements related to social responsibility and community development and to concretely experience the outcomes of empathy in engagement with those in need. For example, one group designed an entertainment activity for the elderly, treated in a ward in a local hospital; another project organized freetime activities for refugees in a welcome centre, teaching the foreigners English while playing board games together.

4. Project presentation: group-graded, $\mathbf{3 0 \%}$. The small groups built a 30 -minute presentation to describe their project purpose, aims, SWOT analysis, organization, stakeholders, main outcomes, audience feedback and personal lessons learned. Besides introducing their project, the students practiced designing and delivering a persuasive group presentation that was built according to a pattern and that used transitions.

5. Reflective journal: individually graded pass/fail, $\mathbf{1 0 \%}$. The students submitted a journal upon course end, reflecting on the weekly activities, contents and, in particular, their personal sentiments and lessons learned. They were to pay particular attention to any triggers of personal transformation in the course environment and analyze possible changes in their mindsets, values, thinking or world view.

\subsection{Student feedback}

As always with new openings and experiments, it is crucial to gather student feedback and not only rely on teacher experiences and sentiments. In this pilot endeavor, student reactions were collected through two channels: reflective journals and the centralized, anonymous e-feedback system managed automatically by the university. The overall grade for the course in the pilot group was $4.42 / 5$, which is satisfactory for a pilot but naturally leaves room for improvement. The criticism revolved around the intensive deadline schedule, early morning classes, and the level of difficulty of the abstract writing assignment.

As the journals constituted one of the graded course assignments and could therefore not be submitted anonymously, the evaluations are overwhelmingly positive and cannot be analyzed as entirely authentic. In general, the journals conveyed appreciation of the unconvential course themes and the concrete ways of learning in class:

- "This course isn't like anything I have been to before."

- "This course was different from other courses in that it focused more on the practical than the theoretical."

- "This course happily surprised me because it focused on specific skills that assist students to strengthen their relationships and build positive emotions. The course was very interesting and useful for me because it was totally different than other available courses."

Some students felt more encouraged to speak, share and interact, thanks to the warm atmosphere: 
- "Lessons had a pleasant ambience. Usually I try as hard as I can not to speak English and stay quiet, but speaking out loud was easier this time."

- "Thanks to this course and the amount we did oral practises, I finally got my confidence back in speaking English."

The most glaring experience was the Do Good project:

- "Do Good assignment was the reason I came to this course. Doing something good to other people makes a positive change to my mood and helping others is always enjoyable."

- "During the project, I learned how impactful something ordinary to myself can be to others."

- "We had to do a project during the course which was the best part of the course. Our topic was about teaching middle school children how to create a simple web page with HTML5 and CSS. We enjoyed doing the project and it made us happy. The project was an amazing and impressive experience that I will never forget."

- "The text from the second lesson was very touching and really got me thinking about the difference one can make in the lives of others, even with small deeds. It's possible to substantially increase their happiness (and your own) by just caring about them, whether it's by realizing that you've been neglecting someone (like I had been doing with my grandmother) or seeing the opportunity to make contact with someone you might not even know yet."

- "The group project was something extraordinary that was truly satisfying to carry out. Even though the task was quite unconventional, its connection to the themes of the course was very well explained and thus it was a meaningful experiment related to the course. The group assignment broadened my view of all the possible actions that people could take to help other people."

\section{Conclusions}

The primary purpose of this paper was to advocate systems intelligence as an emerging competence requirement in the engineering world. The literature reviewed here urges for a subsequent revision of engineering programs to integrate such personal competences that have predictive value in terms of career progress, well-being at work, effectiveness, team interaction, leader success, subordinate outcomes and organizational productivity.

Fortunately, emotional and social intelligence competences can be incorporated into engineering syllabi without disrupting the remainder of the programs [44]. This paper shared a pedagogical experiment from a university of technology that equips students with systemic capabilities. The course design with its accent on systemic abilities leaned on the idea of bi-directional causality, highlighting individuals' sense of responsibility for and ownership of the systems we are part of. Inclusion of socioemotive topics and, in particular, systems intelligence, provides a logical extension and continuation to communication education and an avenue for deepening the recently incorporated theme of social responsibility on the university agenda. As concrete 
classroom practices, the course promoted self-awareness, self-affirmation and selfagency as platforms for initiating an engineering community transformation, which requires a reformation of the student self.

The endeavor pursued change on two levels. On the manifested level of human behavior, the pilot experimented with pedagogy for practicing empathy and social awareness; on the intrapersonal level, it provided tools for self-awareness and selfaffirmation. These are pivotal goals for any learner or professional in the systemic world.

A secondary purpose of this paper was to describe a modest effort adding systems intelligence to an engineering curriculum as a theme and learning objective. The analysis shows that the topic was well-received and students found the learning contents relevant. The course feedback, reflective journals, extraordinarily low drop-out rate and teacher perceptions confirm that it is possible to top the already packed engineering curriculum with themes and subjects outside the traditional core - the use of integrated pedagogy provides a complementary rather than a competing strategy.

One limitation, however, undermining the objective analysis of the course outcomes may stem from the novelty value attached to any new theme. Further studies and farther-extending follow-up is needed to identify the authentic impact of systems intelligence themes and to rule out positive bias derived from the inclusion of any novel and refreshing content. Another bias should be acknowledged in relation to the students likely to attend this course: since the course was offered as a component integrated to the parent course, the attendees were keen on and aware of the topics in the first place. The key challenge within the bigger university system would, however, be attracting the masses with no prior knowledge or background in socio-emotive skilling.

Integration overall has proven to be an effective method for using classroom time efficiently without hurdling student concentration, as the integrated elements supplement core curricula rather than compete for attention. Paradoxically, peripheric topics such as systems intelligence seem to be shifting to the centre within organizational research, while technical expertise is witnessing a slight dismissal in industrial productivity studies.

Instead of narrow-mindedly accentuating cognitive abilities and permanent traits, industrial recruitment and career promotion should cherish individuals with motivation and drive for personal growth, but fostering such personal pursuits ought to begin already at the university. This will eventually benefit industrial productivity, when socially and emotively capable individuals color their workplaces with higher ideals in caring and sharing, which both represent profit-driving features of team dynamics [45].

\section{$5 \quad$ References}

[1] Boyatzis, R.; Rochford, K.; Cavanagh, K. "Emotional intelligence competencies in engineer's effectiveness and engagement". Career Development International, 2017, Vol. 22(1), pp. 70-86. https://doi.org/10.1108/CDI-08-2016-0136 
[2] Bolanakis, D.; Kotsis, K.; Laopoulos, T. "Switching from computer to microcomputer architecture education". European Journal of Engineering Education, 2010, 35(1), pp. 9198. https://doi.org/10.1080/03043790903312162

[3] Gilbert, D.; Held, M.; Ellzey, J.; Bailey, W.; Young, L. "Teaching 'community engagement' in engineering education for international development: Integration of an interdisciplinary social work curriculum". European Journal of Engineering Education, 2015, Vol. 40(3), pp. 256-266. https://doi.org/10.1080/03043797.2014.944103

[4] Glavic, P.; Lukman, R.; Lozano, R. "Engineering education: environmental and chemical engineering or technology curricula - a European perspective". European Journal of Engineering Education, 2009, Vol. 34(1), pp. 47-61. https://doi.org/10.1080/0304379080 2710193

[5] Horila, T. \& Valo, M. 2016. "Yhteinen vuorovaikutusosaaminen tiimissä" (Translated by P.L.: Shared interaction competence in a team). Prologi, 2006, pp. 46-58.

[6] Gilbert, D.; Held, M.; Ellzey, J.; Bailey, W.; Young, L. "Teaching 'community engagement' in engineering education for international development: Integration of an interdisciplinary social work curriculum". European Journal of Engineering Education, 2015, Vol. 40(3), pp. 256-266. https://doi.org/10.1080/03043797.2014.944103

[7] Nederström, M. Personality Assessment and Self-Other Rating Agreement. Moderators and Implications of Agreement. Jyväskylä University, Dissertation, Jyväskylä Studies in Education, Psychology and Social Research, 577, 2017.

[8] Monaghan, C.; Bizumic, B.; Reynolds, K.; Smithson, M.; Johns-Boast, L.; van Rooy, D. "Performance of student software development teams: the influence of personality and identifying as team members". European Journal of Engineering Education, 2015, Vol. 40(1), pp. 52-67. https://doi.org/10.1080/03043797.2014.914156

[9] Boyatzis, R.; Rochford, K.; Cavanagh, K. "Emotional intelligence competencies in engineer's effectiveness and engagement". Career Development International, 2017, Vol. 22(1), pp. 70-86. https://doi.org/10.1108/CDI-08-2016-0136

[10] Bar-On, R. "The Bar-On model of emotional-social intelligence (ESI)". Psicothema, 2006, 18, pp. 13-25.

[11] Lappalainen, P. (2012) Socially Competent Leadership - predictors, impacts and skilling in engineering. Lappeenranta University of Technology, Dissertation, 347, 2012.

[12] Saarinen, E. \& Hämäläinen, R. "The Originality of Systems Intelligence". Published in Hämäläinen, R. \& Saarinen, E. (Eds): Essays on Systems Intelligence. Aalto University, Ssytems Analysis Laboratory, 2010.

[13] Saarinen, E. "Life-Philosophical Lecturing as a Systems-Intelligent Technology of the Self”. Journal of Philosophical Research, 2015, Vol. 40(9999), pp. 263280. https://doi.org/10.5840/jpr201540Supplement33

[14] Monaghan, C.; Bizumic, B.; Reynolds, K.; Smithson, M.; Johns-Boast, L.; van Rooy, D. "Performance of student software development teams: the influence of personality and identifying as team members". European Journal of Engineering Education, 2015, Vol. 40(1), pp. 52-67. https://doi.org/10.1080/03043797.2014.914156

[15] Bar-On, R. "The Bar-On model of emotional-social intelligence (ESI)". Psicothema, 2006, 18, pp. 13-25.

[16] Goleman, D. Social Intelligence. The New Science of Human Relationships. Arrow Books. The UK, 2007.

[17] Goleman, D. \& Boyatzis, R. \& McKee, A. "Primal Leadership. The Hidden Driver of Great Performance”. Harvard Business Review, 2001, Dec, pp. 42-41. 
[18] Lappalainen, P. Työyhteisötaidot - esimiehiin ja alaisiin kohdistuvat osaamisvaatimukset (Translated by P.L.: Work community skills). Lappeenranta University of Technology. Report 47. ISBN 978-952-265-746-6, 2015.

[19] Saarinen, E. "Life-Philosophical Lecturing as a Systems-Intelligent Technology of the Self". Journal of Philosophical Research, 2015, Vol. 40(9999), pp. 263280. https://doi.org/10.5840/jpr201540Supplement33

[20] Saarinen, E. "Life-Philosophical Lecturing as a Systems-Intelligent Technology of the Self". Journal of Philosophical Research, 2015, Vol. 40(9999), pp. 263280. https://doi.org/10.5840/jpr201540Supplement33

[21] Bowen, J. "Emotion in Organization. Resources for Business Educators". Journal of Management Education. 2014, Vol. 38(1), pp. 114-142. https://doi.org/10.1177/10525 $\underline{62913488110}$

[22] Saarinen, E. "Life-Philosophical Lecturing as a Systems-Intelligent Technology of the Self". Journal of Philosophical Research, 2015, Vol. 40(9999), pp. 263280. https://doi.org/10.5840/jpr201540Supplement33

[23] Dashborough, M.; Ashkanasy, N.; Tee, E.; Tse, H. "What goes around comes around: How meso-level negative emotional contagion can ultimately determine organizational attitudes toward leaders". The Leadership Quarterly, 2009, Vol. 20(4), pp. 571-585. https://doi.org/10.1016/j.leaqua.2009.04.009

[24] Fredrickson, B. \& Branigan, C. "Positive emotions broaden the scope of attention and thought-action repertoires. Cognition and Emotion, 2005, Vol. 19(3), pp. 313-332. https://doi.org/10.1080/02699930441000238

[25] Boyatzis, R.; Rochford, K.; Cavanagh, K. "Emotional intelligence competencies in engineer's effectiveness and engagement". Career Development International, 2017, Vol. 22(1), pp. 70-86. https://doi.org/10.1108/CDI-08-2016-0136

[26] Mumford, M. \& van Doorn, J. "The Leadership of Pragmatism, Rethinking Franklin in the Age of Charisma". The Leadership Quarterly, 2001, Vol. 12, pp. 279-309. https://doi.org/10.1016/S1048-9843(01)00080-7

[27] Lappalainen, P. Työyhteisötaidot - esimiehiin ja alaisiin kohdistuvat osaamisvaatimukset (Translated by P.L.: Work community skills). Lappeenranta University of Technology. Report 47. ISBN 978-952-265-746-6, 2015.

[28] Heikka, J. \& Waniganayake, M. "Pedagogical leadership from a distributed perspective within the context of early childhood education". International Journal of Leadership in Education, 2011, Oct-Dec, 14(4), pp. 499-512. https://doi.org/10.1080/13603124.2011. 577909

[29] Ronen, S. \& Mikulincer, M. "Predicting employees' satisfaction and burnout from managers' attachment and caregiving orientations". European Journal of Work and Organizational Psychology. 2012, Vol. 21(6), pp. 828-849. https://doi.org/10.1080/1359432X .2011 .595561

[30] Rouhiainen-Neunhäuserer, M. Johtajan vuorovaikutusosaaminen ja sen kehittyminen (Translated by P.L.: Managerial interaction ability and its development). Jyväskylä University, Dissertation, 2009.

[31] Dörnyei, Z. The Psychology of Second Language Acquisition. Oxford University Press, 2009.

[32] Kokkonen, M. \& Pulkkinen, L. "Extraversion and Neuroticism as Antecedents of Emotion Regulation and Dysregulation in Adulthood". European Journal of Personality, 2001, Vol. 15, pp. 407-424. https://doi.org/10.1002/per.425

[33] Thompson, R. \& Meyer, S. "Socialization of emotion regulation in the family". Published in Gross, J. (Ed.): Handbook of Emotion Regulation. New York, Guilford Press, 2007. 
[34] Duse, D.-M.; Duse, C.S.; Deac, C. "The Quality of Academic Staff: Student Assessment versus an evaluation of the emotional intelligence". 2009, SEFI conference paper. Rotterdam.

[35] Kets de Vries, M. The Leadership Mystique. A User's manual For the Human Enterprise. Pearson Education Limited. The Great Britain, 2001.

[36] Duse, D.-M.; Duse, C.S.; Deac, C. "The Quality of Academic Staff: Student Assessment versus an evaluation of the emotional intelligence". 2009, SEFI conference paper. Rotterdam.

[37] Goleman, D. \& Boyatzis, R. \& McKee, A. "Primal Leadership. The Hidden Driver of Great Performance". Harvard Business Review, 2001, Dec, pp. 42-41.

[38] Boyatzis, R. \& Akrivou, K. "The ideal self as the driver of intentional change. Intentional change from a complexity perspective". Journal of Management Development, 2006, Vol. 25(7), pp. 624-642. https://doi.org/10.1108/02621710610678454

[39] Saarinen, E. "Life-Philosophical Lecturing as a Systems-Intelligent Technology of the Self'. Journal of Philosophical Research, 2015, Vol. 40(9999), pp. 263280. https://doi.org/10.5840/jpr201540Supplement33

[40] Fredrickson, B. \& Branigan, C. "Positive emotions broaden the scope of attention and thought-action repertoires. Cognition and Emotion, 2005, Vol. 19(3), pp. 313-332. https://doi.org/10.1080/02699930441000238

[41] Bar-On, R. "The Bar-On model of emotional-social intelligence (ESI)". Psicothema, 2006, 18, pp. 13-25.

[42] Stinson, D.; Logel, C.; Shepherd, S; Zanna, M. "Rewriting the Self-Fulfilling Prophecy of Social Rejection: Self-Affirmation Improves Relational Security and Social Behavior up to 2 Months Later". Psychological Science, 2011, Vol. 22(9), pp. 1145-1149. https://doi.org/10.1177/0956797611417725

[43] Goleman, D. Social Intelligence. The New Science of Human Relationships. Arrow Books. The UK, 2007.

[44] Boyatzis, R.; Rochford, K.; Cavanagh, K. "Emotional intelligence competencies in engineer's effectiveness and engagement". Career Development International, 2017, Vol. 22(1), pp. 70-86. https://doi.org/10.1108/CDI-08-2016-0136

[45] Solis, E. \& Monroy, V. "Between love and war: The effects of affective commitments". Proceedings of the Academy of Organizational Culture, Communications and Conflict, 2014, Vol. 19(2), pp. 3-4.

\section{Author}

Pia Lappalainen, D.Sc (Tech) and MA (English and French philology, pedagogics and communications), is a researcher in the field of organizations and management. She investigates pedagogy for teaching leadership to engineers at Aalto University, Finland, where she works as a lecturer.

Article submitted 05 June 2017. Published as resubmitted by the author 13 August 2017. 